\title{
Temperature monitoring in large volume spread footing foundations: case study "Parque da Cidade" - São Paulo
}

\section{Monitoramento de temperatura em sapata de fundação de grande porte: estudo de caso "Parque da Cidade" - SP}
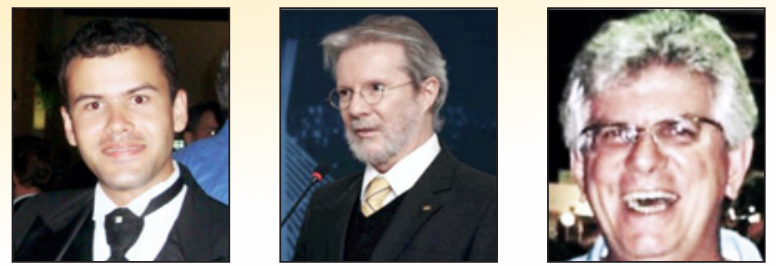

D. cOUTO a

douglas.couto@concretophd.com.br

P. HELENE b,c paulo.helene@poli.usp.br

L. C. ALMEIDA a almeida@fec.unicamp.br

\begin{abstract}
In recent years, the construction of foundation elements from large-volume reinforced concrete is becoming increasingly common. This implies a potential increase in the risk of cracks of thermal origin, due to the heat of hydration of cement. Under these circumstances, these concrete elements need to be treated using the mass concrete theory, widespread in dam construction, but little used when designing buildings. This paper aims to present a case study about the procedures and problems involved in the construction of a spread footing with a volume of approximately $800 \mathrm{~m}^{3}$ designed for the foundation of a shopping center in São Paulo, Brazil.
\end{abstract}

Keywords: mass concrete, foundations, monitoring, temperature, cracking.

\section{Resumo}

Atualmente, tem sido cada vez mais comum a concepção de elementos de fundações em concreto armado de grandes volumes. Essa situação, geralmente implica num aumento potencial do risco do surgimento de fissuras de origem térmica, devido ao calor de hidratação do cimento. Nessas circunstâncias, tais elementos precisam ser tratados no enfoque da teoria referente ao concreto massa, muito difundida em barragens, mas ainda pouco utilizada no projeto de estruturas de edificações. Neste breve contexto, este artigo apresenta um estudo de caso contemplando os procedimentos e problemas envolvidos na concepção e execução de uma sapata de fundação com cerca de $800 \mathrm{~m}^{3}$ projetada para a fundação de um Shopping Center na cidade de São Paulo, SP.

Palavras-chave: concreto-massa, fundações, monitoramento, temperatura, fissuração. 


\section{Introduction}

One of the principal problems of engineering of mass concrete dams is the control of thermal-origin cracking, due to the heat of hydration produced from the natural exothermic reactions of cement hydration. Portland cement, when mixed with water, initiates an exothermic reaction, releasing a large amount of heat.

During this reaction, the concrete undergoes expansive deformation, proportional to its coefficient of thermal dilatation. As this reaction happens in early-age concrete, when the material is in the transition phase between the fresh and hardened state, the expansive deformation induces low-level tension in the concrete, principally compression and shear stress that is easily supportable by concrete at an early age.

During the hydration stage, and concrete hardening, the structural element also exchanges heat with the environment until its internal temperature is balanced with that of the external environment, starting from the outer surface of the concrete. It is during this stage that the risk of cracking increases, because the compressed concrete element that expanded in the early ages, begins to contract, often unequally, creating tensile strain gradients which the concrete is unable to bear because it still has too little resistance strength.

During contraction, internal stress tensions arise, whose magnitude depends on the existing boundary conditions (e.g. degree of restriction, thermal properties, amount and type of materials in the mix, as well as the geometry of the element and environment conditions). These tensions can overcome the tensile strength of the early-age concrete, culminating in the cracking of the structure if proper care has not been taken.

It is quite common at worksites today to make use of large volume foundation elements for a variety of reasons, such as the need for increased stiffness in the foundation, proximity to pillars and the consequent association of their support elements, and even just to simplify construction.
With the advent of high-rise buildings, the tendency is to require foundation elements with more stiffness in order to bear increasingly heavy loads, and this is only possible by significantly increasing the size of pile caps and spread footings.

In the city of São Paulo, Brazil there is currently is under construction a shopping mall that required the construction of a very largesized spread footing, requiring a thermal study in order to reliably predict the behavior of the footing with regard to heat of hydration. In this manner, this element has been analyzed according to criteria consistent with large concrete elements, i.e. mass concrete, where a mix design study has been performed with the aim to produce a concrete with a compression resistance compatible with the structural project request (40 MPa), and at the same time consuming the least amount of cement, as well as substituting ice in place of mixing water.

A computational thermal simulation to evaluate the effect of the heat of hydration on this element was also performed. This simulation provided evidence for an appropriate execution procedure, as well as systematic technical monitoring of the spread footing in the field.

Based on these considerations, it is absolutely necessary to present this subject to the Brazilian technical community, in order to educate structural engineers and builders, as well as promote the review of building standards to adopt appropriate methodologies for analysis and construction of large volume concrete elements.

\section{Thermal effects on concrete}

As defined by the literature and by the American Concrete Institute $(\mathrm{ACl})$ [1], a mass concrete structure can be understood as any concrete structure that has a volume and dimensions great enough to make it necessary to adopt measures to deal with the consequences of the heat of hydration of cement. This heat can generate significant variations in volume, and appropriate measures must

\section{Figure 1 - Artist's rendering of Parque da Cidade, in São Paulo, SP}

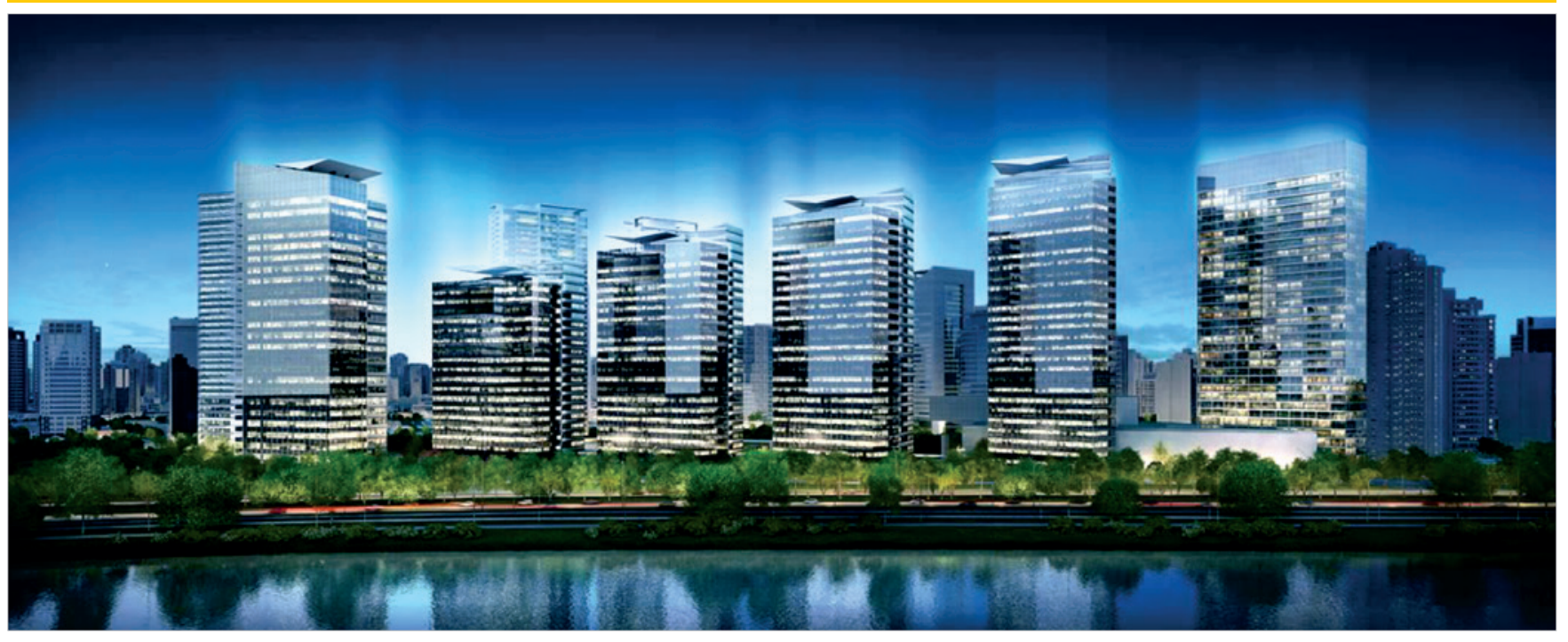


be taken to minimize the formation of cracks, as well as deleterious chemical reactions such as DEF ${ }^{1}$. [1] [2] [3] [4] [5] [6]

The principal hydration reactions that generate a large amount of heat generally occur during the initial 72 hours after the mixture of cement and water. During this time, concrete undergoes mainly compression stress, and because it is just beginning to harden and still considerably plastic, it is able to resist this expansion without problem. [5] [6]

The peak temperature indicates the point in time in which the volumetric expansion tends to cease. After this moment, the process of heat exchange with the environment is accentuated, and the surface layer of the structural element that expanded and reached its peak temperature begins to cool down and shrink. The long term natural tendency is that the element returns to its original volume when the cooling results in an internal temperature in equilibrium with the temperature of the surrounding environment. During this contraction process, tensile stress arises that can exceed the tensile strength of the concrete at this particular age. [7]

According to Mehta and Monteiro [4], the calculation of the tensile stress due to the cooling process of concrete depends of three variables: the elasticity modulus of the concrete, the restriction degree, and the relaxation caused by concrete creep. The mathematical model that expresses the calculation of this stress is given by eq. 1 .

$$
\sigma_{t}=K_{r} \cdot\left[\frac{E}{(1+\varphi)}\right] \cdot \alpha \cdot \Delta T
$$

where:

$\sigma_{t}:$ tension stress;

$K_{r}:$ restriction degree;

$E$ : elasticity modulus;

$\varphi$ : creep coefficient;

$\alpha$ : thermal dilatation coefficient;

$\Delta T$ : temperature gradient

Among these variables, the temperature gradient $(\Delta T)$, is one that deserves most attention, because is the principal cause of deformations, and consequently stress generated in the structural element. The gradient is defined as the difference between the peak temperature and the typical working temperature of the structure, as shown in Fig. 2. [4]

The variation $\Delta T$ is calculated as the sum of the pouring temperature of fresh concrete plus the adiabatic elevation of temperature, minus the ambient temperature. Therefore, the smaller the difference between the ambient temperature (typical working temperature) and the peak temperature, the lower the amount of tension stress that the structural element will be subjected to during the cooling phase. [4] [7] [8]

At the same time that the concrete is being subjected to the risk of thermal cracking, the early-age concrete, if it reaches a temperature above $65^{\circ} \mathrm{C}$ to $70^{\circ} \mathrm{C}$, can suffer expansion due to Delayed Ettringite Formation (DEF). This phenomena occurs due to ettringite crystals not being stable when submitted to temperatures above $65^{\circ} \mathrm{C}$ to $70^{\circ} \mathrm{C}^{2}$, decomposing, and releasing sulfate ions that are absorbed by the calcium silicate hydrate. If, during the lifetime of

\section{Figure 2 - Variation (gradient) of concrete} temperature (MEHTA \& MONTEIRO, 2014)

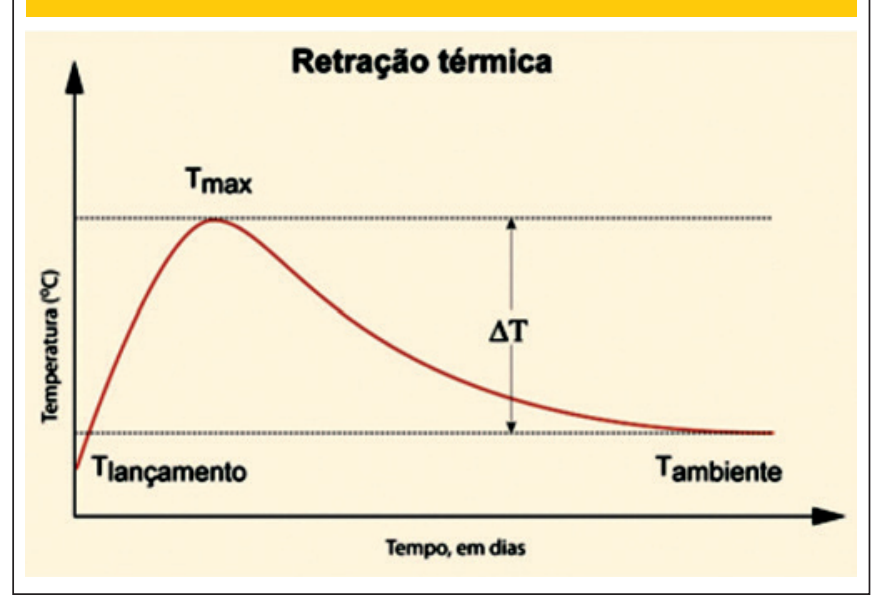

the structure, there is contact with water and porosity, new ettringite may form, causing expansion and potentially cracking. [4] [9] The primary measures usually adopted for the construction of mass concrete elements include reduction of cement consumption, use of cement with admixtures, use of pozzolanic admixtures, addition of slag or microsilica, granulometric packing of the mixture, pre-cooling of concrete and its aggregates, use of ice to replace the mixing water, post cooling of the structure, and even concrete refrigeration using liquid nitrogen. Another measure often taken when working with mass concrete is specifying the compressive concrete strength $\left(\boldsymbol{f}_{c k}\right)$ for ages older than 28 days, thereby requiring less cement consumption. In short, all of these procedures seek to reduce the risk of thermal cracking through the maintenance of as small a thermal gradient as possible between the environment and the concrete element or between the element surface and its interior. [5]

\section{Materials and methodology}

For this study, a spread footing from the structural foundation of a shopping mall from Glebe A, in the real estate development named "Parque da Cidade" in the city of São Paulo, Brazil was used. This spread footing is supported directly by bedrock and on the blueprint it measures $20.8 \mathrm{~m} \times 10.60 \mathrm{~m}$, with a height of $3.50 \mathrm{~m}$, resulting in a volume of approximately $800 \mathrm{~m}^{3}$. The project name of this spread footing is Spread Footing for Columns $P M 281+P M 289+P M 293+P M 294+P M 303$, but it will be referred to simply as "spread footing" in this paper, for ease of mention. The compressive strength of the concrete element $\left(\boldsymbol{f}_{c k}\right)$ specified in the project design, was $40 \mathrm{MPa}$ after 28 days.

For the computer simulation of temperature elevation, a finite element numerical model (FEM) was employed, using the software b4cast. The preliminary FEM analysis indicated the need to construct the spread footing in three layers, each with thickness of approximately $1.20 \mathrm{~m}$, with a lag time of at least five days between

DEF-Delayed Ettringite Formation

There is no clear agreement in the literature about the temperature limit where DEF occurs. Mehta \& Monteiro [4] suggest a maximum limit of $65^{\circ} \mathrm{C}$ before ettringite crystals decompose. On the other hand, Taylor \& Famy [9] suggest a limit of $70^{\circ} \mathrm{C}$ for the same phenomena. 
Temperature monitoring in large volume spread footing foundations: case study "Parque da Cidade" São Paulo
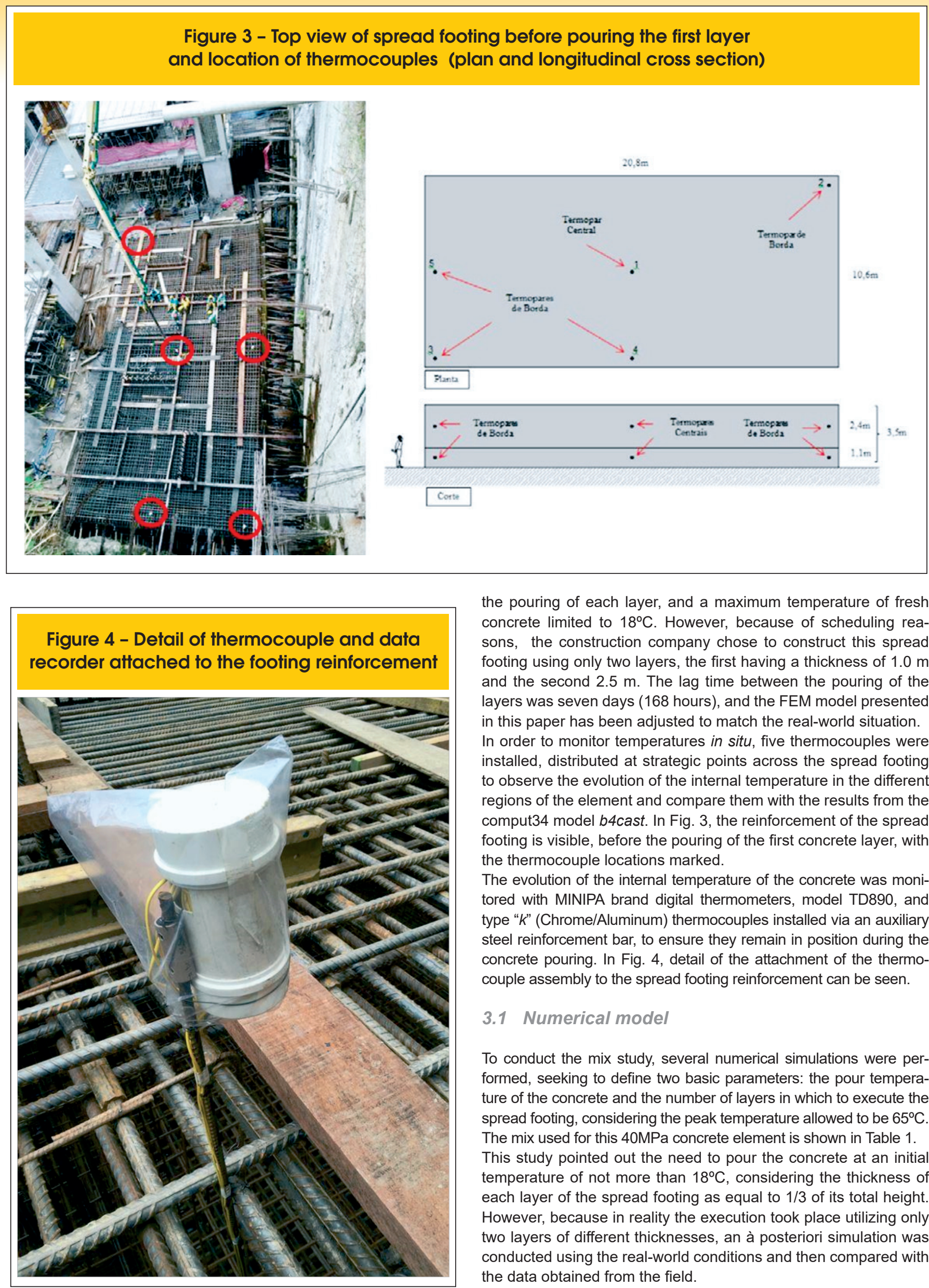

the pouring of each layer, and a maximum temperature of fresh concrete limited to $18^{\circ} \mathrm{C}$. However, because of scheduling reasons, the construction company chose to construct this spread footing using only two layers, the first having a thickness of $1.0 \mathrm{~m}$ and the second $2.5 \mathrm{~m}$. The lag time between the pouring of the layers was seven days (168 hours), and the FEM model presented in this paper has been adjusted to match the real-world situation. In order to monitor temperatures in situ, five thermocouples were installed, distributed at strategic points across the spread footing to observe the evolution of the internal temperature in the different regions of the element and compare them with the results from the comput34 model b4cast. In Fig. 3, the reinforcement of the spread footing is visible, before the pouring of the first concrete layer, with the thermocouple locations marked.

The evolution of the internal temperature of the concrete was monitored with MINIPA brand digital thermometers, model TD890, and type " $k$ " (Chrome/Aluminum) thermocouples installed via an auxiliary steel reinforcement bar, to ensure they remain in position during the concrete pouring. In Fig. 4, detail of the attachment of the thermocouple assembly to the spread footing reinforcement can be seen.

\subsection{Numerical model}

To conduct the mix study, several numerical simulations were performed, seeking to define two basic parameters: the pour temperature of the concrete and the number of layers in which to execute the spread footing, considering the peak temperature allowed to be $65^{\circ} \mathrm{C}$. The mix used for this $40 \mathrm{MPa}$ concrete element is shown in Table 1. This study pointed out the need to pour the concrete at an initial temperature of not more than $18^{\circ} \mathrm{C}$, considering the thickness of each layer of the spread footing as equal to $1 / 3$ of its total height. However, because in reality the execution took place utilizing only two layers of different thicknesses, an à posteriori simulation was conducted using the real-world conditions and then compared with the data obtained from the field. 


\section{Table 1 - Dry materials for concrete mix, measured for a $\mathrm{f}_{\mathrm{ck}}$ of $40 \mathrm{MPa}$, applied in the spread footing (6)}

\begin{tabular}{cc|} 
Material & $\begin{array}{c}\text { Consumption } \\
\left(\mathrm{kg} / \mathrm{m}^{3}\right)\end{array}$ \\
Portland cement CP-III-40-RS & 380.0 \\
Silica fume & 20.0 \\
Natural fine sand (quartz) & 364.0 \\
Artificial sand (crushed powder) (granite) & 546.0 \\
Crushed stone \#0 (granite) & 279.0 \\
Crushed stone \#1 (granite) & 651.0 \\
Additive 1 (MAXCHEM Maximent PX-50) & 2.3 \\
Additive 2 (BASF Glenium SCC 160) & 4.6 \\
Mixing Water (used 100\% ice) & 180.0 \\
Water/(cement+additive) ratio- (W/C) & 0.45 \\
\hline
\end{tabular}

Once the mix of concrete was defined, the temperature gradient was estimated with a mathematical simulation using the maturity method, based on the Arrhenius equation. This method uses the concept of activation energy to simulate a non-instantaneous chemical reaction due to contact between its reagents. [10] [11]

The simulation was performed using the finite element software b4cast, which specifically applies to problems of heat of hydration using the maturity method. Fig. 5 shows the geometrical Footing/

\section{Figure 5 - Footing/Soil geometrical} model, with web discretized

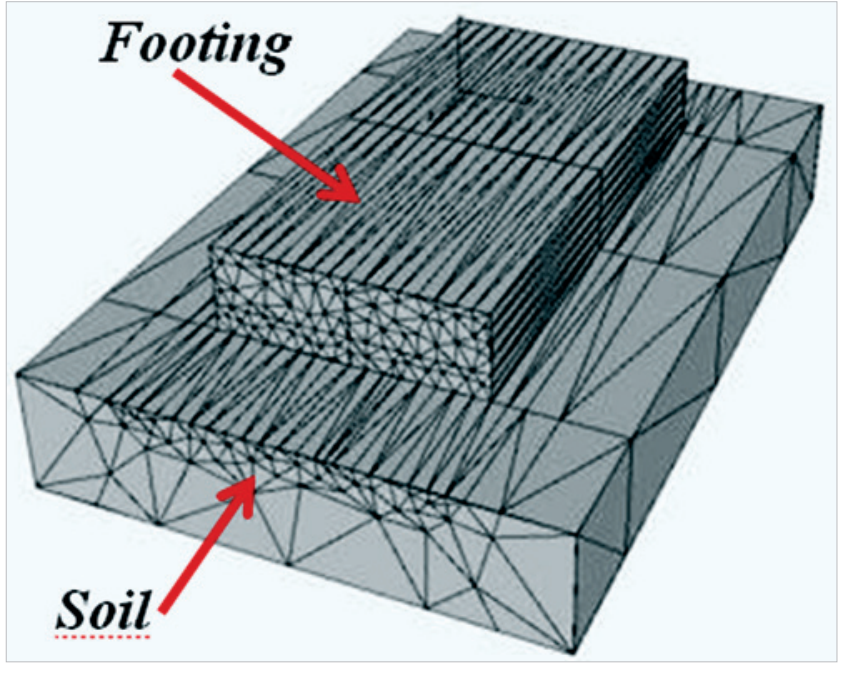

Soil model developed for this analysis, with the tetrahedral finite element web discretized. [11] [12]

After the finite element processing, it was possible to obtain the temperature elevation curves, as well as isothermal curves for the entire concrete element. In Fig. 6 is presented the temperature elevation curves obtained from the numerical model are presented, and in Fig. 7 the isothermal curves from the central cross section of the spread footing are shown.

Figure 6 - Thermocouple temperature curves obtained in the numerical prediction model (FEM - b4cast)

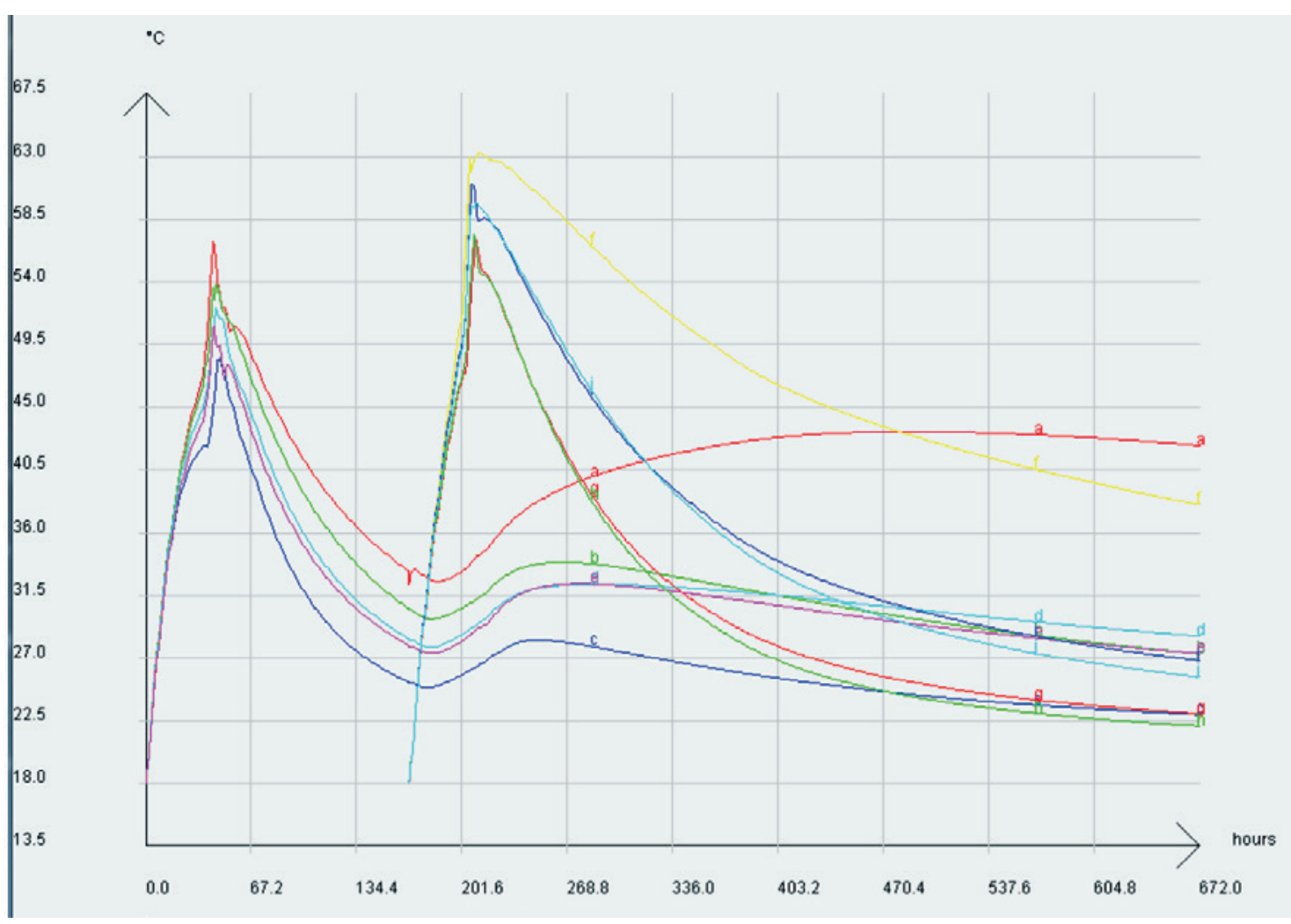


Temperature monitoring in large volume spread footing foundations: case study "Parque da Cidade" São Paulo

Figure 7 - Isothermals on the central cross-section of the spread footing at the moment of peak temperature in the numerical prediction model (FEM - b4cast)
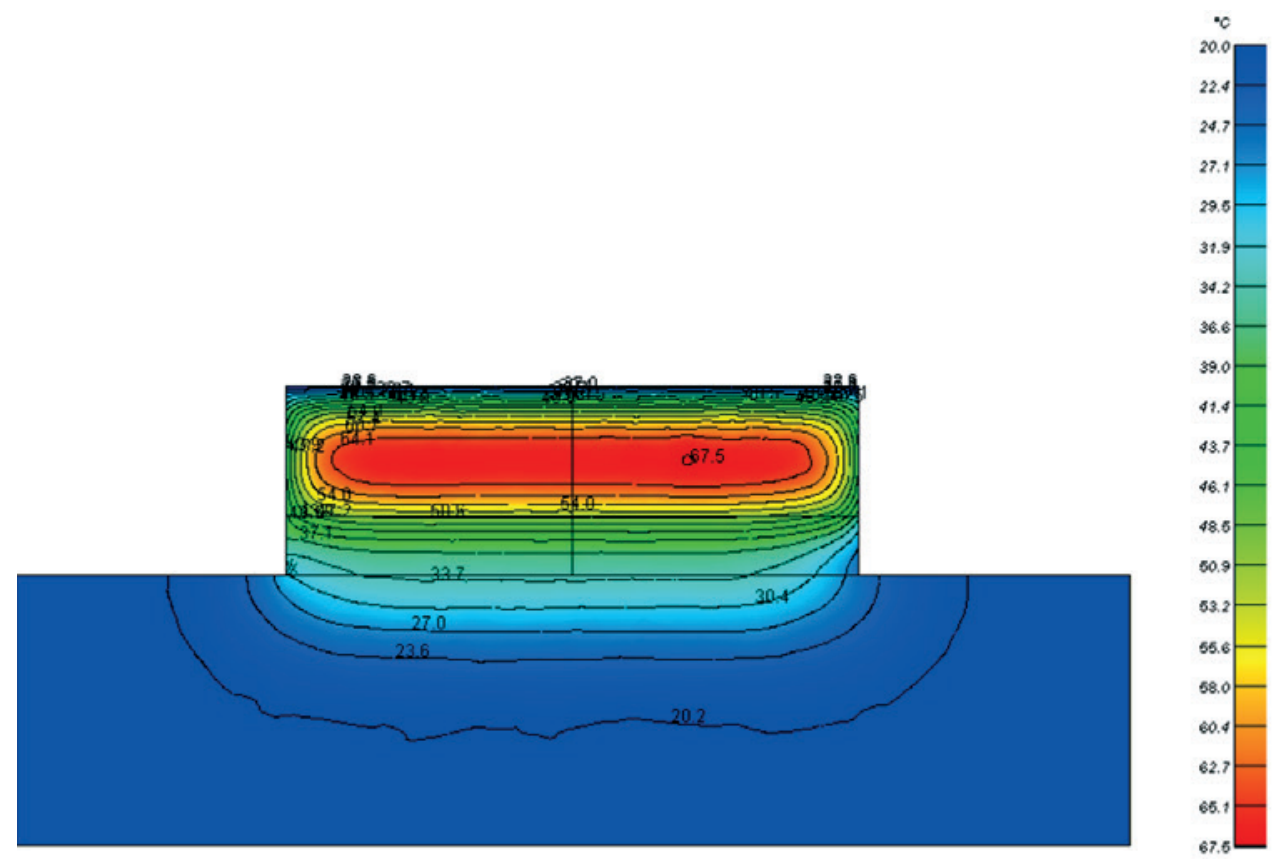

The curves presented in Fig. 6 use the following naming convention: curves "a", " $b$ ", " $c$ ", " $d$ ", and "e" are equivalent to thermocouples $1,2,3,4$, and 5 , respectively, in the first layer. Curves " $f$ ", " $g$ ", " $h$ ", " $p$ " and " $j$ " are equivalent to thermocouples 1, 2, 3, 4, and 5 in the second layer.

The results from the computer model show that the peak temperature should be located near the geometrical center of the spread footing, and it reaches a temperature of $67.5^{\circ} \mathrm{C}$ at time $\mathrm{t}=230 \mathrm{~h}$.
At the thermocouple measuring points, the peak temperature has been estimated to be $63.3^{\circ} \mathrm{C}$ at time $\mathrm{t}=210 \mathrm{~h}$.

\section{Field results}

Seven consecutive days after the pouring of the second concrete layer, the thermocouples were turned off. All five sensors recorded data for the first layer between time $t=0 \mathrm{~h}$ and time $t=171 \mathrm{~h}$, while

\section{Figure 8 - Graphs of temperatures recorded in the first and second layers}

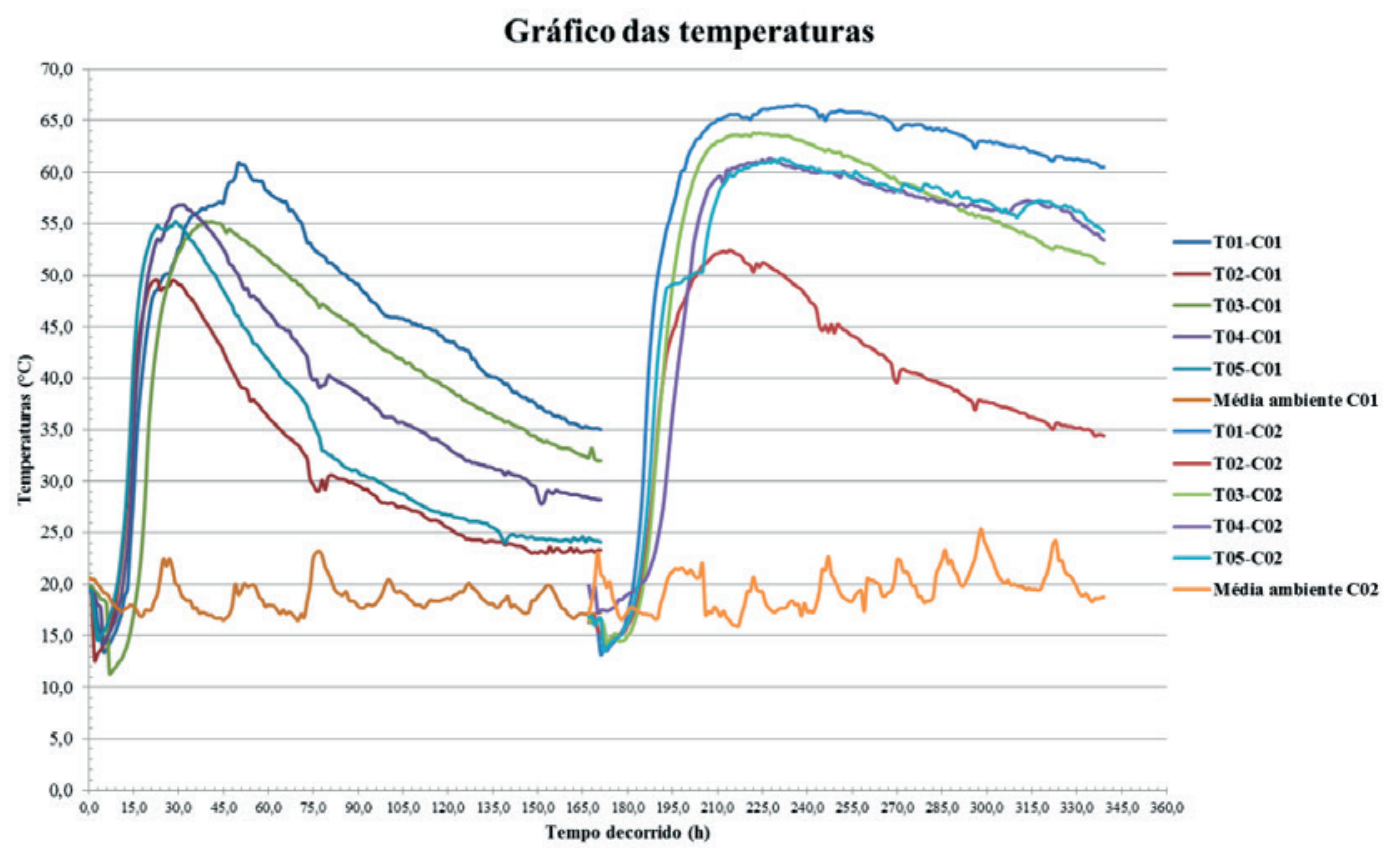


for the second layer, data recording took place between time $t=167 \mathrm{~h}$ and $t=339 \mathrm{~h}$. Each thermocouple had an attached sensor to record the ambient temperature, registering one reading per hour for all sensors simultaneously.

Fig. 8 shows the temperature readings obtained in both layers during the two footing construction events.

Peak temperature in the first layer occurred at time $t=50 \mathrm{~h}$, with a value of $60.9^{\circ} \mathrm{C}$, recorded by thermocouple no. 1. Peak temperature in the second layer occurred at time $t=237 \mathrm{~h}$, with a value of $66.5^{\circ} \mathrm{C}$. Fig. 9 shows the spread footing during the final stages of execution of the second concrete layer.

\section{Discussion}

It can be seen that the mathematical model provided a very good approximation to what was measured in the field. However, the position of the thermocouples did not coincide exactly with the points of peak temperature indicated by the b4cast model.

The peak temperature value predicted by the numerical model was $67.5^{\circ} \mathrm{C}$, occurring at the center of the concrete element at time $t=215 \mathrm{~h}$. The maximum temperature recorded by the thermocouples was $66.5^{\circ} \mathrm{C}$ at time $t=237 \mathrm{~h}$ at thermocouple no. 1 , located in the center of the second layer, a value very close to that predicted by the simulation. The lack an exact match is probably associated with the way that the element was poured, in layers of different thickness.

In numerical analyses involving this type of problem, the lack of an exact correspondence between the physical results and the simulation is acceptable because of the difficulty of obtaining input data for the simulation, such as the cement heat of hydration curve and the diffusivity of the aggregates, as well as random and difficult to model behavior, due the anisotropy and heterogeneity of concrete, that becomes more evident with this type of sensitive analysis, and can affect the results.

In this case, considering the adversities in the field and the particularities of the simulation, it was possible to obtain accurate values, because the actual field data was fed back into the model, without considering deviations in the concrete mix, potential misapplications, or variations in weather and ambient temperature during the concrete pouring. Each concrete layer took approximately eight hours to pour. Both layers began to be poured in the morning, and finished in the evening.

Regarding the choice to construct the spread footing in only two layers, it is important to consider that the peak temperature reached the $65^{\circ} \mathrm{C}$ and $70^{\circ} \mathrm{C}$ limit suggested by the literature. Although it was not possible to observe any thermal cracking, this spread footing may have an increased risk of developing $D E F$ phenomena during its lifetime, since the region is permanently in contact with water.

\section{Final considerations}

Problems involving heat of hydration are becoming more and more frequent in construction engineering, and the accurate forecasting and modeling of this phenomenon have increasing importance and application in structural engineering.

Despite appearing to be, at first glance, a problem of concrete technology, civil and structural engineering must deal with this

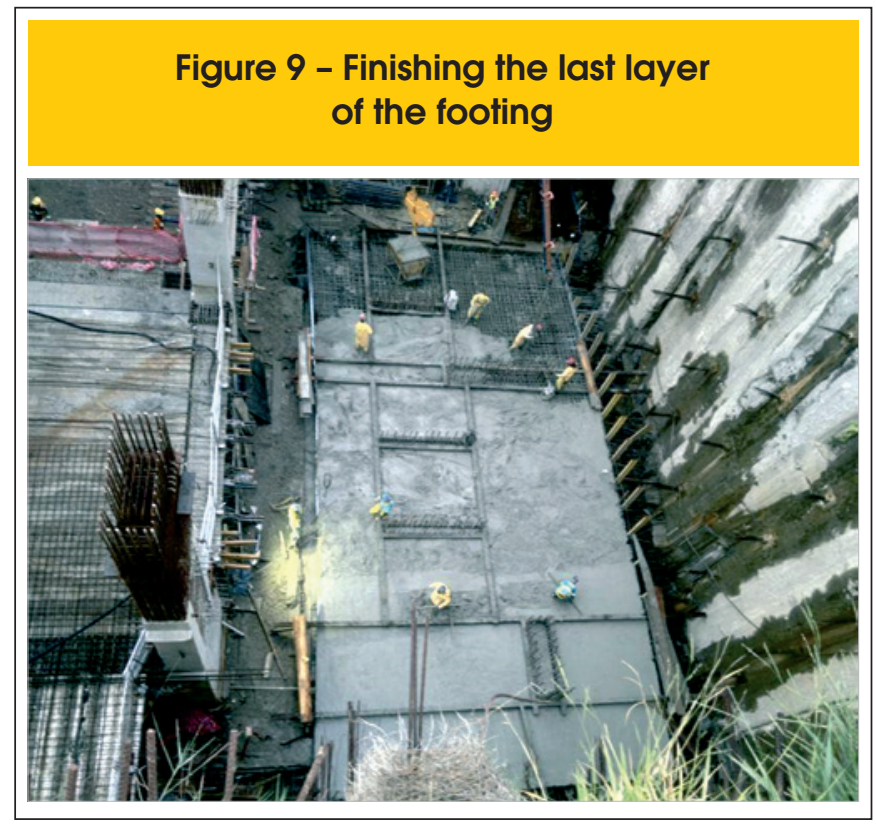

phenomenon, considering that lack of control measures may lead to the emergence of various pathological manifestations that can jeopardize the service life and performance of the structure.

In this case study, it was found that applying the maturity method to analysis of problems involving heat of hydration is completely feasible and provides reliable results, as long as the thermal properties of the concrete and other basic parameters for the computer simulation are known.

The mass concrete theory, though complete and widespread, is frequently applied to the construction of concrete dams, where there is little or no steel reinforcement. In the case of buildings, it is still necessary to evaluate the behavior between early-age concrete and the steel reinforcement, as well their interaction with regard to the degree of restriction and boundary conditions of the structural element, an issue not yet contemplated in standardization and the existing technical literature. [13]

No data regarding the measurement of tension stress generated in concrete due to heat of hydration could be found in the literature review, nor is there any data about the degree of restriction offered to an element because of its height. A suggestion for further research would be to monitor an element with these characteristics in order to measure tension stresses, providing new data and increasing knowledge in this area.

\section{Acknowledgments}

The authors would like to thank Odebrecht Real Estate Developments (OR), especially engineers Fábio Gonçalves Felipe and Eduardo Perri Muccia, who permitted and supported the carrying out of this case study, at the worksite of "Parque da Cidade-SP", under construction in the city of São Paulo, SP, Brazil. A special thanks is also given to engineers Carlos Britez, Ricardo Boni, Reginaldo Rocha, and Juan Gadea, from PhD Engineering, for all of their support during the field tests, numerical simulations, and data analysis. 


\section{References}

[1] AMERICAN CONCRETE INSTITUTE. ACI 207.1R-05 Guide to mass concrete. Farmington Hills. ACl, 2005.

[2] AMERICAN CONCRETE INSTITUTE. ACI 207.2R-07 Report on Thermal and Volume Change Effects on Cracking of Mass Concrete. Farmington Hills. ACl, 2007.

[3] ISAIA, G. C.; et. al. Concreto: Ciência e tecnologia. $1^{\text {a }}$ ed. 2 Vol. Ed. IBRACON: São Paulo, 2011.

[4] MEHTA, P. K.; MONTEIRO, P. J. M. Concrete: Microstructure, Proprieties and Materials. 4th. ed. McGraw-Hill, New York 2014

[5] VICENTE, G. R.; KUPERMAN, S. C.; FUNAHASHI Jr., E. I. Thermal Cracks in Foundations Blocks: When Concrete Should be Cooled? $56^{\circ}$ Congresso Brasileiro do Concreto IBRACON. Anais. Natal, 2014.

[6] BONI, R.; VASCONCELLOS, A.; BRITEZ, C.; ROCHA, R.; HELENE, P. Case study involving concreting of large foundations elements. Case Parque da Cidade-SP $56^{\circ}$ Congresso Brasileiro do Concreto - IBRACON. Anais. Natal, 2014.

[7] FURNAS. Concretos: Ensaios e Propriedades. São Paulo: Ed. PINI, 1997.

[8] NEVILLE, A. M; BROOKS, J. J. Concrete Technology. 2nd. ed. Pearson Education Ltd.: London, 2010. 448p.

[9] TAYLOR, H. F.; FAMY, C.; SCRIVENER, K. L.; Delayed ettringite formation. Cement and Concrete Research, Volume 31, Issue 5, ELSEVIER, May, 2001. Pages 683-693.

[10] CARINO, N. J.; LEW, H. S. The Maturity Method: From theory to application. American Society of Civil Engineers. Washington, D.C., 2001.

[11] AMERICAN SOCIETY FOR TESTING MATERIALS. ASTM C1074-04 Standard practice for estimating concrete strength by the maturity method. West Conshohocken. ASTM, 2004.

[12] DE SCHUTTER, G. Finite element simulation of thermal cracking in massive hardening concrete elements using degree of hydration based material laws. Computer \& Structures vol.80. Issue 27-30. Pages 2035-2042. Leuven, Belgium, 2002.

[13] ASSOCIAÇÃO BRASILEIRA DE NORMAS TÉCNICAS. NBR 6118: Projeto de estruturas de concreto - Procedimentos. Rio de Janeiro, 2014. 